Agro-Science Journal of Tropical Agriculture, Food, Environment and Extension Volume 10 Number 2 May 2011 pp. $35-41$

ISSN 1119-7455

\title{
COMMUNITY EMPOWERMENT VIA ECONOMIC AND TECHNICAL ASSISTANCE WITH HYBRID PLANTAIN/BANANA ENTERPRISE EXPANSION PROGRAMME IN RIVERS STATE, NIGERIA
}

\author{
Achike, A.I, Okoroafor, U.U, and Mkpado. M. \\ Department of Agricultural Economics \\ University of Nigeria, Nsukka, Nigeria. E-mails: ifeyinwaachike@yahoo.com
}

\begin{abstract}
This study examined implementation strategies, approaches, constraints and revenue generation potentials of hybrid plantain/banana enterprise expansion progamme in Rivers State - a community werment programme funded by USAID in Southern Nigeria. Forty contact farmers directly involved in the project were selected. Primary and secondary data were used. Data analyses involved qualitative techniques, descriptive statistics, Kolmogorov-Simirov test and gross margin analysis. Results showed that implementation strategies and approaches were tailored towards overcoming constraints to the success of the project. Forty-five and thirty two percent gains in income were made by processing hybrid plantain fruits into flour and chips instead of local cultivars. Farmers preferred workshops and services of extension agents to other channels of communication with respect to transfer of innovations. It was recommended among other things that community development programmes should work in line with established and prevalent cultural patterns to avoid lack of interest or poor acceptance and minimal support for the project.
\end{abstract}

Key words: Community empowerment; Hybrid Plantain/Bananas; Small-Scale Enterprise; Nigeria.

\section{INTRODUCTION}

The southern part of Nigeria can be called the plantain/banana belt of the country. This is because the area possesses suitable edaphic and climatic conditions for growing plantains and bananas, and the crops are among the major crops grown in this part of the country. Musa species are grouped according to "ploidy," the number of chromosome sets they contain, and the relative proportion of Musa acuminata (A) and Musa balbisiana (B) in their genome. Most familiar, seedless, cultivated varieties (cultivars) of banana are triploid hybrids (AAA, AAB, ABB). Diploids (AA, AB, BB- Musa acuminata $\times$ balbisiana) and tetraploids (AAAA, AAAB, AABB, ABBB) are much rarer; the latter essentially being experimental hybrids. Plantain, banana and cooking banana whose genotypes are designated as $\mathrm{AAB}, \mathrm{AAA}$ and $\mathrm{ABB}$ respectively are species of the genus Musa (Vuylsteke et al; 1997). The importance of plantain/bananas is underscored by the fact that they are among the major staple food throughout the humid tropics of the world (Chndler 1995). Unripe plantain/bananas are sources of iron, while ripped ones provide mainly energy. Plantain/bananas also are sources of vitamins $\mathrm{A}, \mathrm{B} 6$ and $\mathrm{C}$ as well as potassium (Anonymous 1991). They are easily digestible and as such can serve as part of the first solid food given to infants. Ripe banana can serve as a dessert.

Plantain/bananas are high yielding crops, which form an integral component of taungya farming/Agro-Forestry system in tropical Africa (Nweke et al 1988, Swennen 1990). Although plantain/bananas produce fruits throughout the year, the major harvest occurs in the dry season (December to March). During this period, many food crops are in short supply or difficult to harvest. Plantain/bananas thus, play a vital role in the food security need of millions of people (Alves 1985). This is the case in Africa, which produces $70.8 \%$ of the world plantain/bananas output (FAO 1987). and $25 \%$ of total energy need of 70 million people (Samson 1980). About $80 \%$ of plantain/bananas produced by Nigerian farmers are for market and this accounts for more than $30 \%$ of total farm income (Olarunda 1986). 
Major problems limiting the Production of plantain/bananas include the sigatoka diseases. This takes two forms namely, yellow sigatoka caused by Mycesphaerella musicola which is a fungal-leaf spot that can reduce yield by $30-50 \%$; and black sigatoka whose pathogen is Mycosphaerella fijiensis that causes defoliation by leaf necrosis (Stover and Simmonds 1987, INIBAP, 1987). The outbreak of black sigatoka disease in early 1980s seriously threatened the livelihood and welfare of the millions of people in southern Nigeria that depended on plantain/banana. It is because the devastation caused by the disease on the crops led to a large yield reduction of at least $50 \%$ of expected harvest and in most severe cases it wiped out the entire plantain/bananas in the field (IITA 2003). The best alternative approach for control of sigatoka diseases in plantains is through the breeding of resistant hybrids. This is because sigatoka pathogens are fungi, and small-scale farmers lack the financial capacity to purchase suitable fungicides used by commercial producers and exporters in Africa.

The plantain/bananas improvement programme was established in 1986 following the outbreak of black sigatoka disease. It is specifically aimed at solving the problems associated with plantain/bananas production in Africa (IITA 1988). The International Institute for Tropical Agriculture (IITA) in collaboration with other Agricultural Research Centers such as Fundacion Hondurena de Investigacion Agricola (FHIA), and Center de Recherches Regionales sur Benaniers et plantains, Cameroon (CRBP), embarked on the development of high yielding disease resistant varieties that out yield the best land race by about $100 \%$ with high level of tolerance to the virulent disease (IITA 2003b).

Some of the newly developed hybrids had successfully undergone field trials in multiecological locations through National Agricultural Research and Extension system in Nigeria (NARES). However, problems limiting expansion of hybrids of plantain/bananas are low pace of awareness, acceptance and adoption of the innovation. Effective processing and marketing of the hybrid products such as flour, chips, wine, jam puree and so on were also part of the problem. This is because the organoleptic properties of the hybrid products are different from those of the land race. In order words, apart from introduction of the hybrids to farmers, their processing and utilization were not known to the public which resulted in low market (Ewujowoh 1994).

Most information available to extension officers comprise agronomic practices with little or no information on processing of the produce hybrid plantain/bananas. Thus, despite the nutritive quality, higher yield and disease resistant ability of the hybrids, their trials and adoption were very much limited. In the year 2000, the United State Agency for International Development (USAID) graciously provided support to IITA with which the plantain/bananas expansion programme was lunched on a largescale (IITA 2003b). IITA in collaboration with plantain and Bananas Development Programme (PBDP) of Federal Ministry of Agriculture and National Horticultural Research Institute (NIHORT) served as nucleus of the programme. The programme involved delivery of hybrids of plantain and bananas suckers and other inputs, dissemination of information on improved agronomic practices, sucker multiplication techniques, post-harvest storage and processing techniques.

Ever since the commencement of the programme, research has not fully documented the experiences in Rivers State of Nigeria. For instance, available literature has not provided concise answers to the following questions: what problems did the project face? What implementation strategies made the project a success in Rivers State? This study thus aimed at documenting (i) objectives of the project and implementation strategies used to execute the programme/projects in Rivers state (ii) determination of appropriate channel of transfer of innovation from research centres to farmers, (iii) identification of obstacles to the success of the projects and strategies used to overcome them. (iv) identification of the postharvest/processing technologies disseminated to the formers. ( $v$ ) assessment of the acceptance of the hybrid products since the implementation of the programme. (vi) examine the profitability of the enterprise and (vi) make feasible recommendation based on the findings.

The null hypothesis that guided the study was that there is no preference among farmers in their choice of channels for transfer of innovation of hybrids of plantain/bananas.

\section{MATERIALS AND METHODS}

The study Area: The study was conducted in Rivers State. The state was purposively selected because it was one of the states that benefited from the hybrid plantain/bananas production expansion programme funded by USAID. Besides, the state hosts IITA High Rainfall Station which is located in Onne-Rivers State. The primary occupation of people in rural areas of the state is farming and small-holder farmers dominate the farming population. Major arable crops grown are plantains and bananas as well as cassava and maize. 
Achike, A.I, Okoroafor, U.U, and M. Mkpado.

Sampling procedure: Multi stage purposive sampling techniques were used. This was in order to select the primary contact and collaborating contact farmers involved in the programme. Stage (I) involved the purposive selection of three local government areas that benefited from IITA hybrid plantain/banana expansion programe, Stage (II) is the purposive selection of 4 communities namely Okwale, Ogbidi, Idu and Igwurinta $1 \& 2$ based on the fact that they are areas where plantain/banana production is the major farming enterprise. Stage (III) is the purposive selection of 40 farmer respondents made up of 4 primary contact farmers (first set of farmers trained) and 36 collaborative contact farmers. This means that 10 farmers were selected from each of the 4 communities.

\section{Data Collection and Analytical Techniques}

Primary data were collected through the use of structured questionnaires, oral interviews and observation of field activities. Secondary data were collected from relevant texts, journals and other materials including publications of IITA. Data were analysed using qualitative techniques descriptive statistics and gross margin analysis, while the hypothesis was tested using Kolmogorov - Simirov (K-S) one sample statistics. The K-S test was used to determine if any preference existed in the choice of communication channel for transfer of innovation to farmers. The format and decision rule are stated as:

$\mathrm{D}^{*}=\operatorname{Max} / \mathrm{S}_{\mathrm{n}(\mathrm{x})}-\mathrm{F}_{\mathrm{o}(\mathrm{x})} / \leq \mathrm{D}(1-\alpha ; \mathrm{n})$

Where Max = Maximum

$\mathrm{D}^{*}$ and $\mathrm{D}(\mathrm{I}-\alpha ; \mathrm{n})=$ Calculated and tabulated $\mathrm{K}-$ $\mathrm{S}$ statistics at $\alpha$ probability level for $\mathrm{n}$ number of observation respectively, $/ \mathrm{S}_{\mathrm{n}(\mathrm{x}}-\mathrm{F}_{\mathrm{o}(\mathrm{x})} /=$ absolute value of difference between observed cumulative and calculated probability frequencies respectively.

If $\mathrm{D}^{*}$ is $\leq \mathrm{D}(1-5 \% ; 40)$, there is no preference for channels of communication for transfer of innovation among the farmers.

The implicit format for gross margin analysis per $\mathrm{kg}$ of plantain flour or chips is given as:

\section{Total Revenue (TR) - Total \\ Gross Margin per kg of flour/chips $=\quad$ Variable cost (TVC) \\ RESULTS AND DISCUSSION, $1 \mathrm{~kg}$ of plantain flour/chips \\ Objectives and Implementation Strategies \\ The implementation strategy was} anchored on major objectives of the project which were arrived at during a stakeholders workshop held in September 2000 at the IITA High Rainfall station in Onne, Rivers State and subsequent meetings with IITA PBDP and NIHORT, in consultation with PHIA and

INIBAP. The key objectives and strategies are:

1. Distribution and on-farm evaluation of black sigatoka resistant hybrids and training of farmers.

These were achieved by:

(a) establishment of demonstration plots and monitoring of the plots;

(b) distribution of planting materials on farmer's field days and training farmers in sucker multiplication techniques;

(c) provision and distribution of training manuals and assisting community based organizations (CBOs) as well as individuals to set up Sucker Multiplication Centers (SMCs); and

2. dissemination of improved agronomic practices, alternate post-harvest technologies in processing and marketing of the hybrid products through workshops and training.

\section{Implementation Approach and Rationale for the Choice}

The project adopted rural, farmerparticipatory and community based technology delivery approach in close collaboration with National Agricultural Development Programme and non government organizations (NGOs). These approaches are based on the facts and concepts that:

i. adoption of innovation is strongly influenced by members of social groups;

ii. farmers are keen observers of other farmers' activities to know how to get good yields or good results and who experimented with new methods;

iii. people tend to accept new ideas most easily along with their peers; and

iv. many innovations can originate either from farmers or modified by them to suit their situations 
Table 1: Distribution of OFDPs and VMTs in Rivers State.

\begin{tabular}{llccc}
\hline Local Government & Communities & No. of Farmers & OFDPs (ha) & VMTs (ha) \\
\hline Oyigbo & Okwale & 1 & 0.12 & 0.12 \\
Ogba/Egbema/Ndoni & Idu & 1 & 0.12 & 0.12 \\
Ogba/Egbema/Ndoni & Ogbidi & 1 & 0.12 & 0.12 \\
Ikwere & Igwurinta 1 & 1 & 0.12 & 0.12 \\
Ikwere & Igwurinta 2 & 1 & 0.12 & 0.12 \\
\hline Total & $\mathbf{5}$ & $\mathbf{5}$ & $\mathbf{0 . 6 0}$ & $\mathbf{0 . 6 0}$
\end{tabular}

Table 2: List of Constraints and Strategies Adopted

\begin{tabular}{ll}
\hline Constraints & Strategies Adopted \\
\hline $\begin{array}{l}\text { Scarcity of land and mixed cropping systems commonly } \\
\text { practiced to maximize land use and satisfy food security need }\end{array}$ & $\begin{array}{l}\text { VMTs OFDPs areas were reduced to } 0.12 \text { ha minimum and } \\
\text { provisions were made (if necessary) for } 2 \text { farmers to donate a plot }\end{array}$ \\
limited availability of large plots of land for VMTs and OFDPs, & $\begin{array}{l}\text { each instead of one donating } 2 \text { plots. Farmers were encouraged to } \\
\text { inter crop the hybrid suckers with other arable crops. }\end{array}$ \\
and adoption of hybrids as mono-crops. & $\begin{array}{l}\text { IITA, CRBP and State ADP produced more hybrid suckers. Farmers } \\
\text { whortage of planting materials reduced the pace of adoption of }\end{array}$ \\
the innovation. & $\begin{array}{l}\text { techniques. } \\
\text { Traditional institutions along with the state ADP were engaged to } \\
\text { Inadequate awareness of development programmes in Africa has }\end{array}$ \\
marred success of development projects. & $\begin{array}{l}\text { Regular contact by agricultural extension agents through home and } \\
\text { farm visits helped to sustain interest and adoption. }\end{array}$ \\
\hline Loss of interest in the new technologies. &
\end{tabular}

Source: Field Data, 2004.

\section{Establishment of the Plots}

Establishment of farmers' plots commenced in June 2001; each primary contact famer for the project had two plots of about 0.12 hectares (ha) each for the establishment of Varietal Mixture Trials (VMTs) and On Farm Demonstration plots (OFDPs). The VMTs were designed for the hybrids to act as biological control against the incidence of disease on farmers' local varieties thereby improving their yields. It also allows the farmers to make a good comparison of yields of local varieties with the hybrids as well as preserve the land race for further genetic studies and uses.

The OFDPs were designed to enable farmers assess the performance of the various hybrids along with their best local variety so as to make comparison and selection.

\section{Constraints to Success of the Project and Strategies Adopted}

Constraints to success of the project are presented in Table 2 .
Supply of Logistics: A total of 226 hybrid suckers of plantain and bananas were made available to the primary contact farmers of the programme in Rivers state free of charge. They were planted at $2 \mathrm{~m} \times 3 \mathrm{~m}$ apart. Farmers were assisted with subsidy for labour as well as fertilizers made available through collaborating institutions. Funds were made available for field monitoring and up keep of the VMTs and OFDPs.

\section{Workshop/Training/Field Trips}

Training covered areas of special interest in agronomic practices including sucker multiplication and management techniques and post -harvest technologies such as processing of produce into chips, flour, wine and juice as well as packaging and marketing strategies. Processing of hybrid produce into flour takes place during the dry season (October to March). Interestingly, this period coincided with the peak harvesting period. Processing of produce into chips takes place at anytime. Chips and flour attract higher income during period of scarcity. 
Beside the scheduled training/workshop days, the extension officers were assigned to conduct regular visit and monitoring of the VMTs and OFDPs in collaboration with the primary contact farmers on whose farm lands the plots were established. Both the Primary and collaborative contact farmers were trained during workshop and fieldd visits on OFDPs and VMTs. Information channel preference is shown in table 4. With respect to transfer of innovation, farmers preferred the use of workshops; followed by extension agents other farmers and the media (Table 4). The Kolmogorov-Smironv test for this preference is significant at $5 \%$ probability level. The calculated K-S statistics at $5 \%$ probability level for 40 observations is 0.500 which is greater than tabulated one $(0.215)$. This partially explains why there was very low adoption of the innovations prior to the provision of fund by USAID for expansion of the programme - which largely made use of workshops and extension agents.

Income Generation to Farmers by the Project Income generated involved cash awards, sales of suckers and bunches of plantain/bananas as well as plantain flour and chips.
Cash Awards: Cash awards were given to outstanding/successful farmers during farmers' day exhibitions and world food day programmes to boost competitive spirit in the adoption of the hybrids and recommended technologies.

Marketing of Suckers: The Primary and collaborative contact farmers rapidly multiplied suckers for sale using the sucker multiplication improved technologies gained through workshops. Hybrid suckers were sold at $\$ 50.00$ or $\$ 60.00$ each . an average small-scale farmer can multiply up to 50 suckers within 3 months.

Marketing of processed hybrid products: Plantain flour and chips are sources of higher income to farmers. Table 5 illustrates distribution of farmers according to hybrid produce they sold.

\section{Source: Field Data 2004}

Comparative analysis of income generation by hybrids and local varieties show that bunches of hybrids are larger and attracts higher prices than local varieties/land race. Table 6 illustrates this.

Table 3: Work Shop schedule, Location and Number of Participants Workshop

\begin{tabular}{lll}
\hline Month & Location & No of Participant \\
\hline September 2000 & Onne & 42 farmers \\
December 2000 & Onne & 30 farmers \\
May 2001 & Onne & 20 farmers \\
November 2001 & Okwale & 31 farmers \\
September 2002 & Onne & 10657 farmers \\
December 2002 & Onne & 57 farmers \\
May 2003 & Onne & 10 community organization \\
\hline
\end{tabular}

Source: Adopted from IITA 2003b

Table 4: Frequency Distribution of Farmers According to their Preferred Source of Innovations transfer

\begin{tabular}{lll}
\hline Source of Information & No of Respondents & Percentage \\
\hline Media & 2 & 5 \\
Other farmers & 8 & 20 \\
Extension agents & 10 & 25 \\
Workshops & 20 & 50 \\
Total & $\mathbf{4 0}$ & $\mathbf{1 0 0}$ \\
\hline
\end{tabular}

Source: Field Data, 2004.

Table 5: Distribution of Respondents According to Products of Hybrids Sold.

\begin{tabular}{lll}
\hline Products & No. of Farmers* & Percentage \\
\hline Flour & 27 & 67 \\
Chips & 30 & 75 \\
Suckers & 40 & 100 \\
\hline
\end{tabular}

* Multiple response recorded 
Table 6: Distribution of Respondents According to Average Price Bunch of Earned from Hybrids and Local Cultivars of Plantain/Bananas.

\begin{tabular}{lll}
\hline Price Range (N) & Number of Hybrid Cultivars & Number of Local Cultivars \\
\hline$<100$ & 0 & 7 \\
$100-199$ & 3 & 10 \\
$200-299$ & 5 & 15 \\
$300-399$ & 14 & 8 \\
$400-499$ & 10 & 0 \\
$500-599$ & 8 & 0 \\
\hline Total & $\mathbf{4 0}$ & $\mathbf{4 0}$ \\
\hline
\end{tabular}

Figures in parenthesis are percentages, Source: $\quad$ Computed from Field Data, 2004.

Table 7: Comparison of Revenue from Processed Land Race and Hybrid Cultivars

\begin{tabular}{|c|c|c|c|c|}
\hline Cultivars & $\begin{array}{l}\text { Gross Margin/Kg } \\
\text { Flour }\end{array}$ & $\begin{array}{l}\text { \% Income difference } \\
\text { from cultivars }\end{array}$ & $\begin{array}{l}\text { Gross Margin Chips } \\
\text { kg. }\end{array}$ & $\begin{array}{l}\text { \% Income difference } \\
\text { from cultivars }\end{array}$ \\
\hline Local cultivars & $\$ 220.45$ & 51 & 545.00 & 68.6 \\
\hline Hybrid cultivars & $\$ 432.08$ & & 795.00 & \\
\hline
\end{tabular}

Source: Computed from Field Data 2004.

The explanation of the differences in the gross margins is based on the fact that hybrids possess more dry matter per gramme than local cultivars. Also, even though that the same resources are employed in processing of plantains to flour or chips the quality of the hybrids products attracted higher prices than those of local cultivars. The cost items considered were: cost of plantain bunches, peeling and washing, milling/chopping, cost of drying or frying, and transportation; while the revenue were sales of $1 \mathrm{~kg}$ of plantain flour and $1 \mathrm{~kg}$ of plantain clips. Table 7 shows that 51 and 68.6 percent gains will be made by processing hybrids of plantain into flour and chips respectively instead of processing local cultivars.

\section{Summary and Recommendations}

The study examined the Rivers State experience of community empowerment through economic and technical assistance with Hybrid Plantain/Bananas Enterprise Expansion Programme funded by USAID in southern Nigeria. Plantain/Bananas are major food crops in Rivers State. It has been illustrated that success of the programme was based on: implementation strategies that were strictly used to achieve specific objectives of the programme, rationale for implementation approach were based on facts about behaviours of people with respect to adoption of innovations, the approach also was in consonance with the prevalent cropping systems due to land scarcity and food security need of the farmers.

The project demands on farmers especially with respect to provision of land were reasonably what the farmers could provide and provisions were made for 2 farmers each to provide one piece of land of about 0.12 hectares where one farmer could not provide two pieces of land of 0.12 hectares each for OFDPs and VMTs respectively. Hybrid suckers, fertilizers and training were provided free of charge. Also labour was subsidized for establishment and maintenance of OFDPs and VMTs plots on farmers' lands. Extension agents constantly encouraged farmers to adopt the new technologies. It was determined that farmers preferred workshops and services of extension agents as information channels for transfer of innovation to the media and co-farmers. The hybrid produce attracted higher income to the farmers.

Consequently, the following recommendations are made:

1. Implementation strategies and approaches to development programmes should be flexible and strictly aimed at achieving specific objectives as well as overcoming obstacles to the success of the projects. Such approach makes the programme objective- driven and obstacledismantling as well as sensitive to needs of different situations.

2. Community development programmes should not be against the prevalent cultural pattern to avoid lack of interest or acceptance and minimal support for the projects.

3. Community empowerment intervention should not demand more than what the populace can offer in order for project to reach the target people and enhance adoption of the technologies of the project.

4. Innovations that will earn farmers higher income should be transferred to them 
using workshop and extension agents because they prefer these information channels to others.

\section{ACKNOWLEDGMENT}

The Authors are grateful to USAID for funding the programme from which this article emanated and to staff of IITA Onne, Rivers State, for their technical assistance when this research was conducted.

\section{REFERENCES}

Alves, E.J. (1985) La Industria Banancira en el Brasil. Augura (Columbia) II (2): Pp.47-54.

Anonymous (1991) A Report on a Rapid Rural Appraisal of Bananna Production. Research Bulletin No. 2 Makerere University, Kanu Pale Uganda.

Chandler, S. (1995) 'The nutritional value of Bananas' in S. Gowen (ed) Bananas and Plantains Chapman and Hall Uk.

Ewujinuoh, V. (1994) Research Finds Banana ripe for Cooking. Daily Sun ray May 26 p. 7.

FAO (1987) Food and Agricultural Organisation Year Book Rome.

IITA (1998) IITA Annual Report and Research Highlights 1987/88 Ibadan, Nigeria.

IITA (2003a) "Plantain and Banana Production in Nigeria: A baseline survey" Draft survey Report June, International Institute of Tropical Agriculture, Ibadan.
IITA (2003b) "Delivery and Evaluation of disease - resistant plantain and Banana hybrids and Related Technologies under Smallholder Management Systems in Nigeria" Draft Interim Project Report June, International Institute of Tropical Agriculture, Ibadan.

INIBAP (1996) "Major Banana and Plantain types cultivated around the world" In the Global banana and Plantain network: INIBAP Animal Report 1994 Montpellier, France.

Nweke, F.I., J.E. Njoku and G.F. Wilson (1988) "Productivity and Limitations of Plantain (Musa spp $\mathrm{Cv}$ AAB). Production in Compound Gardens in South-eastern Nigeria" Fruits 43: 161 166

Olorunda, A.O. (1986) "Towards an Ideal Post. Harvest Food Chain" $9^{\text {th }}$ in the series of inaugural lectures for 1986. University Press Ibadan, Nigeria.

Samson, J.A. (1980) Tropical Fruits. Longman London New York.

Stover, R.H. and N.W. Simmonds (1987) Bananas: Tropical Agriculture Series Thrid Edition. John Wiley and Sons. Inc. New York.

Swennen, R. (1990) Plantain Cultivation Under West African Conditions: A Reference Mamah. IITA, Ibadan Nigeria.

Vuylsteke, D.R. Ortiz, R.S.B. Ferris and Z.H. Crouch (1997) "Plantain Improvement" Plant Breeding Reviews 14: 267 - 320. 